\title{
Critical current density in (YBa2Cu307)1x-(PrBa2Cu307)x melt-textured composites
}

Opata, Yuri Aparecido; Monteiro, João Frederico Haas Leandro; Jurelo, Alcione Roberto; Siqueira, Ezequiel Costa

Published in:

Physica C: Superconductivity and its Applications

Link to article, DOI:

10.1016/j.physc.2018.03.005

Publication date:

2018

Document Version

Peer reviewed version

Link back to DTU Orbit

Citation $(A P A)$ :

Opata, Y. A., Monteiro, J. F. H. L., Jurelo, A. R., \& Siqueira, E. C. (2018). Critical current density in $\left(\mathrm{YBa}_{2} \mathrm{Cu}_{3} \mathrm{O}\right)$ - $\left(\mathrm{PrBa}_{2} \mathrm{Cu}_{3}\right)_{3}$ melt-textured composites . Physica C: Superconductivity and its Applications, 549, 407-912. Https://dor.org/10.1016/j.physc.2018.03.005

\section{General rights}

Copyright and moral rights for the publications made accessible in the public portal are retained by the authors and/or other copyright owners and it is a condition of accessing publications that users recognise and abide by the legal requirements associated with these rights.

- Users may download and print one copy of any publication from the public portal for the purpose of private study or research.

- You may not further distribute the material or use it for any profit-making activity or commercial gain

- You may freely distribute the URL identifying the publication in the public portal 


\section{Accepted Manuscript}

Critical Current Density in $\left(\mathrm{YBa}_{2} \mathrm{Cu}_{3} \mathrm{O}_{7-} \delta\right)_{1-\mathrm{x}}-\left(\mathrm{PrBa}_{2} \mathrm{Cu}_{3} \mathrm{O}_{7-} \delta\right)_{\mathrm{x}}$ Melt-Textured Composites

Yuri Aparecido Opata , João Frederico Haas Leandro Monteiro , Alcione Roberto Jurelo, Ezequiel Costa Siqueira

PII: S0921-4534(17)30460-4

DOI: 10.1016/j.physc.2018.03.005

Reference: $\quad$ PHYSC 1253322

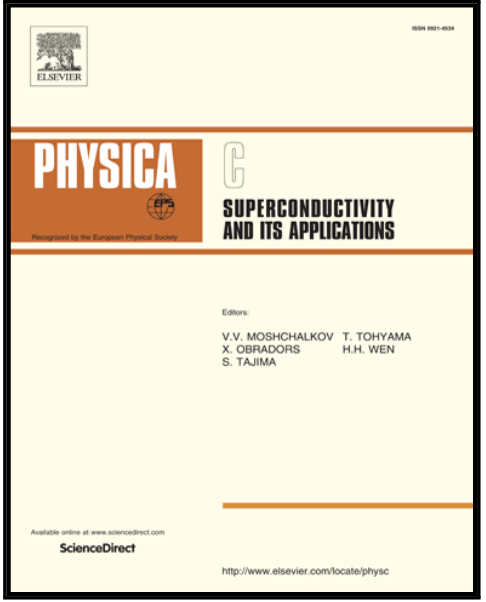

To appear in:

Physica C: Superconductivity and its applications

Received date:

17 September 2017

Revised date:

27 February 2018

Accepted date:

15 March 2018

Please cite this article as: Yuri Aparecido Opata, João Frederico Haas Leandro Monteiro, Alcione Roberto Jurelo, Ezequiel Costa Siqueira, Critical Current Density in $\left(\mathrm{YBa}_{2} \mathrm{Cu}_{3} \mathrm{O}_{7-\delta} \delta\right)_{1-x}$ $\left(\mathrm{PrBa}_{2} \mathrm{Cu}_{3} \mathrm{O}_{7} \delta\right)_{\mathrm{x}}$ Melt-Textured Composites, Physica C: Superconductivity and its applications (2018), doi: 10.1016/j.physc.2018.03.005

This is a PDF file of an unedited manuscript that has been accepted for publication. As a service to our customers we are providing this early version of the manuscript. The manuscript will undergo copyediting, typesetting, and review of the resulting proof before it is published in its final form. Please note that during the production process errors may be discovered which could affect the content, and all legal disclaimers that apply to the journal pertain. 


\section{Highlights}

- Melt-textured $\left(\mathrm{YBa}_{2} \mathrm{Cu}_{3} \mathrm{O}_{7-} \delta\right)_{0.95}-\left(\mathrm{PrBa}_{2} \mathrm{Cu}_{3} \mathrm{O}_{7-} \delta\right)_{0.05}$ sample successfully produced.

- Tiny reduction in critical temperature.

- Strong reduction of critical current density.

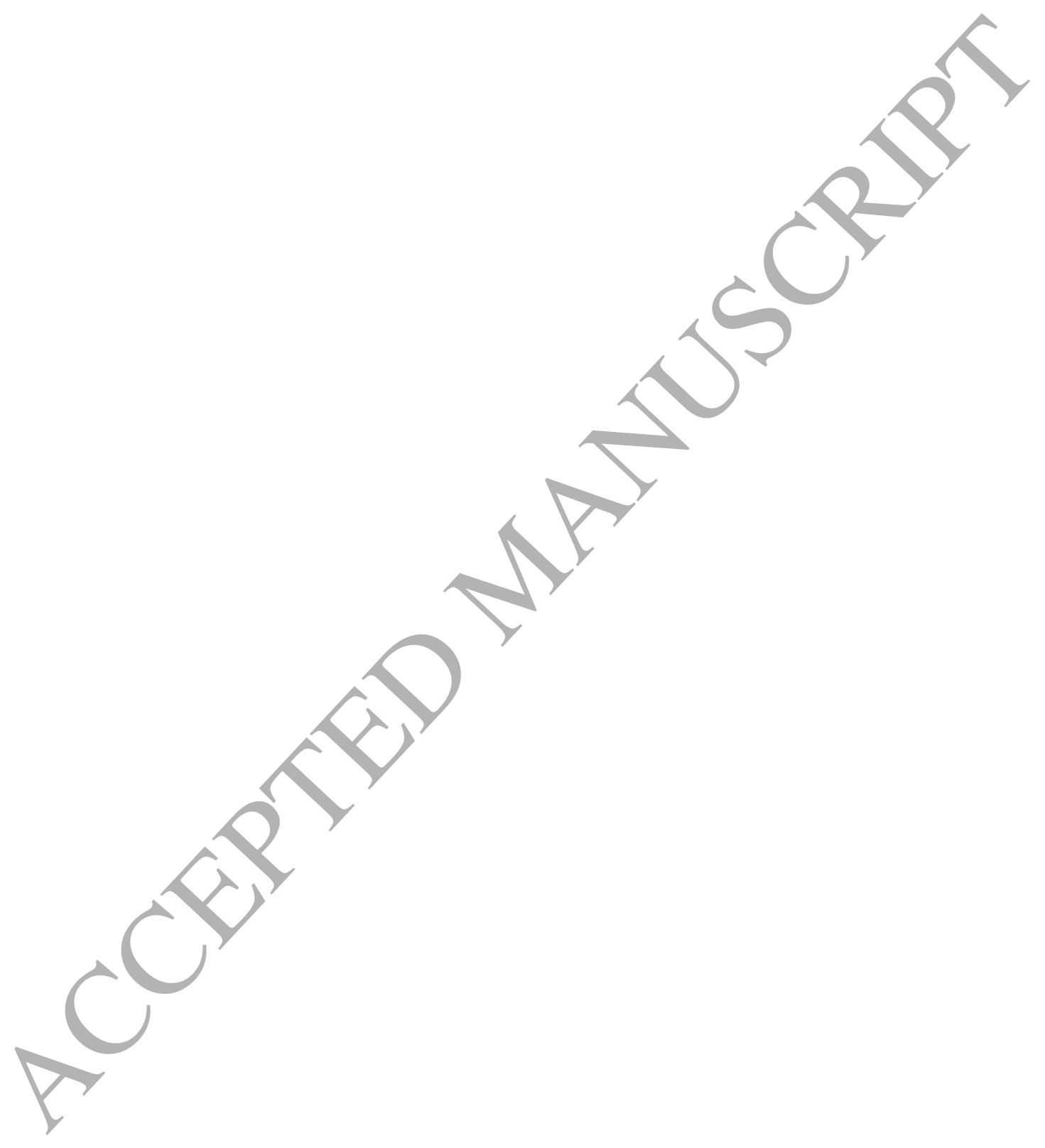


Critical Current Density in $\left(\mathrm{YBa}_{2} \mathrm{Cu}_{3} \mathrm{O}_{7-\delta}\right)_{1-\mathrm{x}}-\left(\mathrm{PrBa}_{2} \mathrm{Cu}_{3} \mathrm{O}_{7-\delta}\right)_{\mathbf{x}}$ Melt-

\section{Textured Composites}

\section{Yuri Aparecido Opata}

Department of Energy Conversion and Storage, Technical University of Denmark, Frederiksborgvej 399, 4000 Roskilde, Denmark

João Frederico Haas Leandro Monteiro*, Alcione Roberto Jurelo

Departamento de Física, Universidade Estadúal de Ponta Grossa, Av. Gen.

Carlos Cavalcanti 4748, 84.030-000, Ponta Grossa, Paraná, Brazil.

(Physics Department, State University of Ponta Grossa)

\section{Ezequiel Costa Siqueira}

Universidade Tecnológica Federal do Paraná, Campus Ponta Grossa, Avenida Monteiro Lobato 1787, 84.016-210, Ponta Grossa, Paraná, Brazil

(Federal Technological University of Paraná, Campus Ponta Grossa)

${ }^{*}$ Corresponding Author: 
João Frederico Haas Leandro Monteiro

Departamento de Física (Physics Department)

Universidade Estadual de Ponta Grossa (State University of Ponta Grossa)

Av. Gen. Carlos Cavalcanti n ${ }^{\circ} 4748$

$84.030-000$

Ponta Grossa, Paraná, Brazil

Tel : +55 4232203044

Fax : +55 4232203042

e-mail: jfhlmonteiro@hotmail.com

Keywords:

YBCO; Praseodymium; Composites; Melt textured; Characterization; Critical current density.

\section{ABSTRACT}

Melt textured $\left(\mathrm{YBa}_{2} \mathrm{Cu}_{3} \mathrm{O}_{7-} \delta\right)_{1-\mathrm{x}}-\left(\mathrm{PrBa}_{2} \mathrm{Cu}_{3} \mathrm{O}_{7-} \delta\right)_{\mathrm{x}}$ composites $(x=0.00$ and $x=$ $0.05)$ were grown using the top seeding method. The effect of the $\mathrm{PrBa}_{2} \mathrm{Cu}_{3} \mathrm{O}_{7-\delta}$ phase on the growth process and the modification of the microstructure as well as on the physical properties was analyzed. X-ray 
analyses indicated that both pure and Pr-doped samples present an orthorhombic superconducting phase. From resistivity measurements for $\mathrm{YBa}_{2} \mathrm{Cu}_{3} \mathrm{O}_{7-\delta}$ and $\left(\mathrm{YBa}_{2} \mathrm{Cu}_{3} \mathrm{O}_{7-\delta}\right)_{0.95}-\left(\mathrm{PrBa}_{2} \mathrm{Cu}_{3} \mathrm{O}_{7-\delta}\right)_{0.05}$ samples, the $T_{c}^{a b}$ did not change and was around $90.5 \mathrm{~K}$. However, from magnetic measurements, the superconductivity was observed in critical temperatures $T_{C}=92.9 \mathrm{~K}$ and $92.4 \mathrm{~K}$ for $\mathrm{YBa}_{2} \mathrm{Cu}_{3} \mathrm{O}_{7-\delta}$ and $\left(\mathrm{YBa}_{2} \mathrm{Cu}_{3} \mathrm{O}_{7-\delta}\right)_{0.95}-\left(\mathrm{PrBa}_{2} \mathrm{Cu}_{3} \mathrm{O}_{7-\delta}\right)_{0.05}$ samples, respectively. The $\mathrm{YBa}_{2} \mathrm{Cu}_{3} \mathrm{O}_{7} \delta$ sample showed higher critical current densities than those shown by the $\left(\mathrm{YBa}_{2} \mathrm{Cu}_{3} \mathrm{O}_{7-\delta}\right)_{0.95}-\left(\mathrm{PrBa}_{2} \mathrm{Cu}_{3} \mathrm{O}_{7-\delta}\right)_{0.05}$ sample, with values of $J_{C}=5.85 \times 10^{5} \mathrm{~A} / \mathrm{cm}^{2}$ and $4.72 \times 10^{5} \mathrm{~A} / \mathrm{cm}^{2}$, respectively. This paper also discusses the importance of Pr substitution on nano- and micron-metre scales to enhance $J_{C}(H)$.

\section{Introduction}

The $\mathrm{YBa}_{2} \mathrm{Cu}_{3} \mathrm{O}_{7-\delta}(\mathrm{Y}-123)$ superconductor is considered one of the most interesting materials for presenting high critical temperature $T_{C}$ and critical current density $\tau_{c}$. In $\mathrm{YBa}_{2} \mathrm{Cu}_{3} \mathrm{O}_{7-\delta}$ polycrystalline samples, very low critical current density is observed, usually in the range $10^{3} \mathrm{~A} / \mathrm{cm}^{2}$. This low $J_{C}$ value has been attributed to the anisotropic superconducting properties and the presence of grain boundaries [1]. On the other hand, melt growth process has enabled us to fabricate large single grain bulk $\mathrm{YBa}_{2} \mathrm{Cu}_{3} \mathrm{O}_{7-} \delta$ superconductors in which, with addition of the fine dispersed $\mathrm{Y}_{2} \mathrm{BaCuO}_{5}(\mathrm{Y}$ 211) particles in the matrix, critical current density values in the order of $10^{5}$ $\mathrm{A} / \mathrm{cm}^{2}$ at $77 \mathrm{~K}$ were easily obtained [2]. The high $J_{C}$ value observed in melt textured $\mathrm{Y}-123$ has made this material highly attractive for technological applications. 
$\mathrm{PrBa}_{2} \mathrm{Cu}_{3} \mathrm{O}_{7-\delta}(\mathrm{Pr}-123)$ is also very interesting since it exhibits the same orthorhombic structure as the $\mathrm{YBa}_{2} \mathrm{Cu}_{3} \mathrm{O}_{7-\delta}$ and other similar rare-earth (RE) compounds. $\mathrm{Pr}$ has a large size ion radius and also a big spin magnetic moment when compared to other rare-earth element [3]. In $\mathrm{Y}_{1-x} \mathrm{Pr}_{x} \mathrm{Ba}_{2} \mathrm{Cu}_{3} \mathrm{O}_{7}$. $\delta$ compound, a transition occurs from superconductor to an antiferromagnetic insulator at $x \cong 0.56$ [4], and this is largely affected by the $\mathrm{RE}$ ionic size in $\mathrm{RE}_{1-x} \mathrm{Pr}_{x} \mathrm{Ba}_{2} \mathrm{Cu}_{3} \mathrm{O}_{7-\delta}$. The $x$ critical value decreases with increasing $\mathrm{RE}$ ionic size. Some theories are used to explain critical temperature $T_{C}$ versus $x$ relation in this system: hole filling [5], pair breaking [6], hole location [7] and percolation [8-10].

The ionic size effect is coupled with the problem of how $\operatorname{Pr}$ doping deteriorates the superconductor state and consequently the superconductor/insulator transition [8-10]. It is believed that the deterioration is produced with the localization of holes around the $\operatorname{Pr}$ ion, occurring due to the hybridization between $\mathrm{Pr}-4 \mathrm{f}$ orbital and neighboring $\mathrm{O}$ $2 \mathrm{p}$ in the $\mathrm{CuO}_{2}$ plane. Yoshida et al. studied the transport properties of $\mathrm{Y}_{1}$. ${ }_{x} \mathrm{Pr}_{x} \mathrm{Ba}_{2} \mathrm{Cu}_{3} \mathrm{O}_{7-\delta}$ polycrystalline samples and composites consisting of $\mathrm{YBa}_{2} \mathrm{Cu}_{3} \mathrm{O}_{7-\delta}$ and $\mathrm{PrBa}_{2} \mathrm{Cu}_{3} \mathrm{O}_{7-\delta}[8-10]$. The results were described as a mixed crystalline solid solution consisting of two kinds of crystal unit cells $\mathrm{Y}-123$ and Pr-123. In this model, the system is regarded as a $2 D$ site-percolation structure built along the $a b$-plane with structural resolutions on nano- and micron-metre scales [8-10].

The aim of this paper is to investigate the microstructure and physical properties of melt textured $\left(\mathrm{YBa}_{2} \mathrm{Cu}_{3} \mathrm{O}_{7-\delta}\right)_{1-\mathrm{x}}-\left(\mathrm{PrBa}_{2} \mathrm{Cu}_{3} \mathrm{O}_{7-} \delta\right)_{\mathrm{x}}$ composites ( $x=0.00$ and $x=0.05)$. As a transition occurs from superconductor to an antiferromagnetic insulator state at $x \cong 0.56$, then we decided to produce a sample with low Pr concentration (around $5 \%$ ) to avoid undesired effects. The samples were prepared by employing the top-seeding method and characterized using optical microscopy, scanning electron microscopy, X-ray 
diffraction, transport and magnetization measurements. The effect of $\mathrm{PrBa}_{2} \mathrm{Cu}_{3} \mathrm{O}_{7-\delta}$ phase on the critical temperature and critical current density was studied.

\section{Experimental Details}

The melt textured samples were obtained using a top-seeding method. The seed used in this study was an $\mathrm{NdBa}_{2} \mathrm{Cu}_{3} \mathrm{O}_{7-\delta}$ single crystal. The same thermal procedure was used for the preparation of $\mathrm{YBa}_{2} \mathrm{Cu}_{3} \mathrm{O}_{7-\delta}(\mathrm{Y}-123)$ and $\left(\mathrm{YBa}_{2} \mathrm{Cu}_{3} \mathrm{O}_{7-} \delta\right)_{0.95}-\left(\mathrm{PrBa}_{2} \mathrm{Cu}_{3} \mathrm{O}_{7-} \delta\right)_{0.05}((\mathrm{Y}-\mathrm{Pr})-123)$ composites. The $\mathrm{YBa}_{2} \mathrm{Cu}_{3} \mathrm{O}_{7-} \delta$ and $\mathrm{PrBa}_{2} \mathrm{Cu}_{3} \mathrm{O}_{7-} \delta$ phases were prepared separately but using the same thermal route. High purity $\mathrm{Y}_{2} \mathrm{O}_{3}, \mathrm{Pr}_{6} \mathrm{O}_{11}, \mathrm{BaCO}_{3}$ and $\mathrm{CuO}$ powders were used. For $\mathrm{YBa}_{2} \mathrm{Cu}_{3} \mathrm{O}_{7-\delta} / \mathrm{PrBa}_{2} \mathrm{Cu}_{3} \mathrm{O}_{7-\delta}$ composite, our seeded melt growth method employed a precursor material containing 75 wt. \% $\mathrm{YBa}_{2} \mathrm{Cu}_{3} \mathrm{O}_{7-\delta}$ and $25 \mathrm{wt}, \% \mathrm{Y}_{2} \mathrm{BaCuO}_{5}$ (commercial powder). Also, each sample received the addition of $1 \mathrm{wt} . \% \mathrm{CeO}_{2}$ to limit particle-coarsening effects and to increase liquid capillarity [11]. The temperature was increased with a 40 ${ }^{0} \mathrm{C} / \mathrm{h}$ ramp rate up to $920{ }^{\circ} \mathrm{C}$ and held there for $24 \mathrm{~h}$. Then, the temperature was increased with a $0.5{ }^{\circ} \mathrm{C} / \mathrm{h}$ ramp rate up to $1040{ }^{\circ} \mathrm{C}$ (melt temperature) and held there for $3 \mathrm{~h}$. It was then cooled at $0.5{ }^{\circ} \mathrm{C} / \mathrm{h}$ to $980{ }^{\circ} \mathrm{C}$. Finally, the temperature was reduced to room temperature at the rate of $40{ }^{\circ} \mathrm{C} / \mathrm{h}$. For $\left(\mathrm{YBa}_{2} \mathrm{Cu}_{3} \mathrm{O}_{7-\delta}\right)_{0.95}-\left(\mathrm{PrBa}_{2} \mathrm{Cu}_{3} \mathrm{O}_{7-\delta}\right)_{0.05}$ composites, the melt temperature used was $1050{ }^{\circ} \mathrm{C}$. Finally, for both samples, oxygen annealing was carried out at $420^{\circ} \mathrm{C}$ for $120 \mathrm{~h}$ in $\mathrm{O}_{2}$ flow. 
The microstructure of the composites was investigated using scanning electron microscopy (Shimadzu SSX 550 model). The phases formed were analyzed through powder-ray diffraction using $\mathrm{CuK}_{\alpha}$ radiation (Shimadzu XRD 6000 model). Rietveld refinements of crystal structures were performed using GSAS and EXPGUI [12-13] software. Transport measurements were carried out by the four-probe method and with a low-frequency-low-current AC technique. Magnetization measurements were carried out in $15 \mathrm{~K}$ using a Quantum Design PPMS magnetometer in magnetic fields up to $\mu_{0} H=8$ T. Critical current densities were determined by the Bean model from the hysteresis loops.

\section{Results and Discussion}

The structure of all samples was investigated using $\mathrm{X}$-ray diffraction. Patterns for melt textured $\mathrm{YBa}_{2} \mathrm{Cu}_{3} \mathrm{O}_{7-} \delta$ and $\left(\mathrm{YBa}_{2} \mathrm{Cu}_{3} \mathrm{O}_{7-\delta} \delta\right)_{0.95}-\left(\mathrm{PrBa}_{2} \mathrm{Cu}_{3} \mathrm{O}_{7-\delta}\right)_{0.05}$ composites are presented in Figure 1. The measurements demonstrate that the pattern for the melt textured $\left(\mathrm{YBa}_{2} \mathrm{Cu}_{3} \mathrm{O}_{7-\delta}\right)_{0.95}-\left(\mathrm{PrBa}_{2} \mathrm{Cu}_{3} \mathrm{O}_{7-\delta}\right)_{0.05}$ was very similar to that of the $\mathrm{YBa}_{2} \mathrm{Cu}_{3} \mathrm{O}_{7-\delta}$ composite. However, the peaks corresponding to $\mathrm{Y}-123$ and $\mathrm{Pr}-123$ were not separately observed in the experimental XRD patterns. Using the GSAS and EXPGUI software, the lattice parameters $a, b, c$ and $V$ for melt textured $\mathrm{YBa}_{2} \mathrm{Cu}_{3} \mathrm{O}_{7-\delta}$ and $\left(\mathrm{YBa}_{2} \mathrm{Cu}_{3} \mathrm{O}_{7}\right.$ $\delta)_{0.95}-\left(\mathrm{PrBa}_{2} \mathrm{Cu}_{3} \mathrm{O}_{7-} \delta\right)_{0.05}$ composites were calculated. They are shown in Table I and are in agreement with the published results from other studies [14]. Also, the agreement factors and goodness-of-fit $(S)$ are small and therefore reliable. 
Table I: Lattice parameters $a, b, c$ and $V$ for $\mathrm{YBa}_{2} \mathrm{Cu}_{3} \mathrm{O}_{7-\delta}$ and $\left(\mathrm{YBa}_{2} \mathrm{Cu}_{3} \mathrm{O}_{7-\delta}\right)_{0.95}-\left(\mathrm{PrBa}_{2} \mathrm{Cu}_{3} \mathrm{O}_{7-\delta}\right)_{0.05}$ melt textured composites.

\begin{tabular}{|l|c|c|c|c|}
\hline \multicolumn{3}{|c|}{$\mathrm{YBa}_{2} \mathrm{Cu}_{3} \mathrm{O}_{7} \delta$} \\
\hline \multicolumn{1}{|c|}{$\boldsymbol{a}(\AA)$} & $b(\AA)$ & $c(\AA)$ & $V\left(\AA^{3}\right)$ \\
\hline $\mathrm{YBa}_{2} \mathrm{Cu}_{3} \mathrm{O}_{7-} \delta$ & $3.81873(6)$ & $3.88722(8)$ & $11.6820(1)$ & $173.410(5)$ \\
\hline \multicolumn{1}{|c|}{$\mathrm{Y}_{2} \mathrm{BaCuO}_{5}$} & $12.1816(2)$ & $5.6603(1)$ & $7.1327(2)$ & $491.81(2)$ \\
\hline$R_{w p}=5.4 \%$ & & & \\
$R_{\text {exp }}=4.3 \%$ \\
$S=1.2$ \\
$R_{F}=10 \%$
\end{tabular}

\begin{tabular}{|l|c|c|c|c|}
\hline \multicolumn{5}{|l|}{$\left(\mathrm{YBa}_{2} \mathrm{Cu}_{3} \mathrm{O}_{7-} \delta\right)_{0.95}-\left(\mathrm{PrBa}_{2} \mathrm{Cu}_{3} \mathrm{O}_{7-} \delta\right)_{0.05}$} \\
\hline \\
\hline $\mathrm{YBa}_{2} \mathrm{Cu}_{3} \mathrm{O}_{7-} \delta$ & $3.8203(1)$ & $3.8890(2)$ & $11.6886(5)$ & $173.66(1)$ \\
\hline $\mathrm{Y}_{2} \mathrm{BaCuO}_{5}$ & $12.191(1)$ & $5.6609(5)$ & $7.1376(7)$ & $492.59(9)$ \\
\hline
\end{tabular}




$$
\begin{aligned}
& R_{w p}=8.1 \% \\
& R_{\text {exp }}=6.3 \% \\
& S=1.1 \\
& R_{F}=19 \%
\end{aligned}
$$

SEM images of $\mathrm{YBa}_{2} \mathrm{Cu}_{3} \mathrm{O}_{7-d}(\mathrm{a}-\mathrm{b})$ and $\left(\mathrm{YBa}_{2} \mathrm{Cu}_{3} \mathrm{O}_{7-\delta}\right)_{0.95}-\left(\mathrm{PrBa}_{2} \mathrm{Cu}_{3} \mathrm{O}_{7-\delta}\right)_{0.05}(\mathrm{c}-$ d) melt textured composite for $a b-$ and $a(b) c$ - plane are shown in Figure 2. A typical microstructure is seen in this figure, which is consistent with the high density of grains embedded in a matrix $\mathrm{Y}(\mathrm{Pr})-123$. Typical small and large $\mathrm{Y}$ 211 particles are also present. Y-211 particles are trapped in the interior of the domains and some residual phase is observed in the boundary region. This might indicate an incomplete peritectic reaction. A detailed image of the $\mathrm{BaCeO}_{3}$ particles dispersed regardless of the plane in the phase matrix can be also observed in the figure. The composition of these inclusions is not homogeneous and there are significant differences in size.

In general, great changes were not observed in the microstructure of the ( $\mathrm{Y}$ Pr) - 123 sample, when compared with the sample $Y-123$. And also, as expected, from the SEM images, it was not possible to observe individual grains based on $y-123$ and $\mathrm{Pr}-123$ (only $5 \%$ of the grains). Also, the presence and the distribution of $\mathrm{BaCeO}_{3}$ particles was the same for both samples, not showing dependence with Pr doping. On the other hand, a great increase in porosity was observed in the Pr-doped sample. Moreover, for samples $(Y-P r)-123$, it was possible to observe a great increase in microcracks parallel to (001) planes, which is clearly shown in Figure 2(d). 


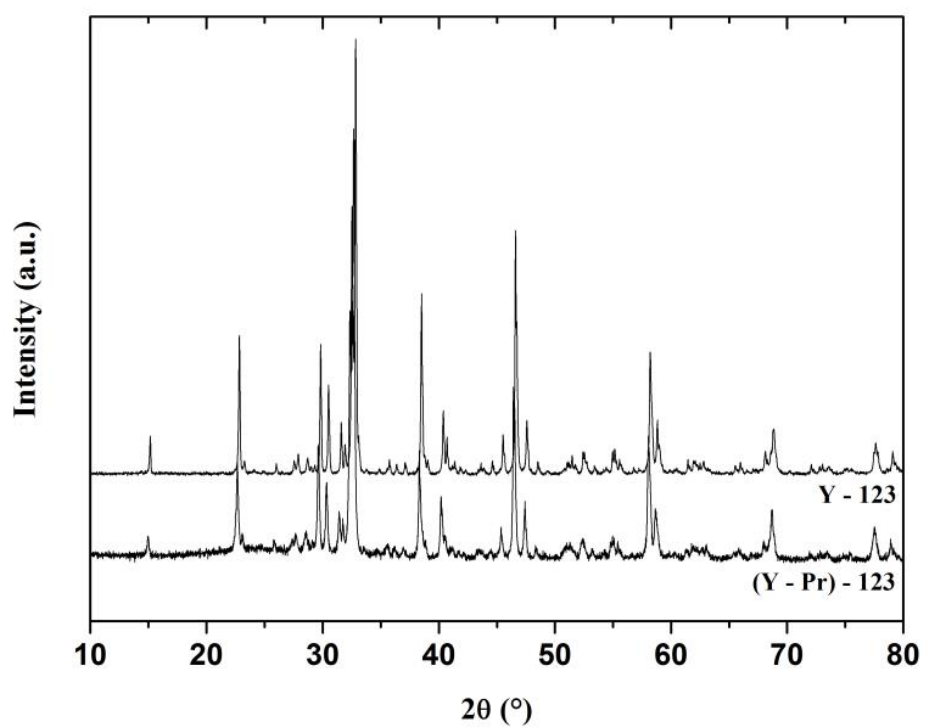

Figure 1: Representative $\mathrm{X}$-ray diffraction patterns for melt textured $\mathrm{YBa}_{2} \mathrm{Cu}_{3} \mathrm{O}_{7-} \delta$ and $\left(\mathrm{YBa}_{2} \mathrm{Cu}_{3} \mathrm{O}_{7-} \delta\right)_{0.95}-\left(\mathrm{PrBa}_{2} \mathrm{Cu}_{3} \mathrm{O}_{7-} \delta\right)_{0.05}$ composites.

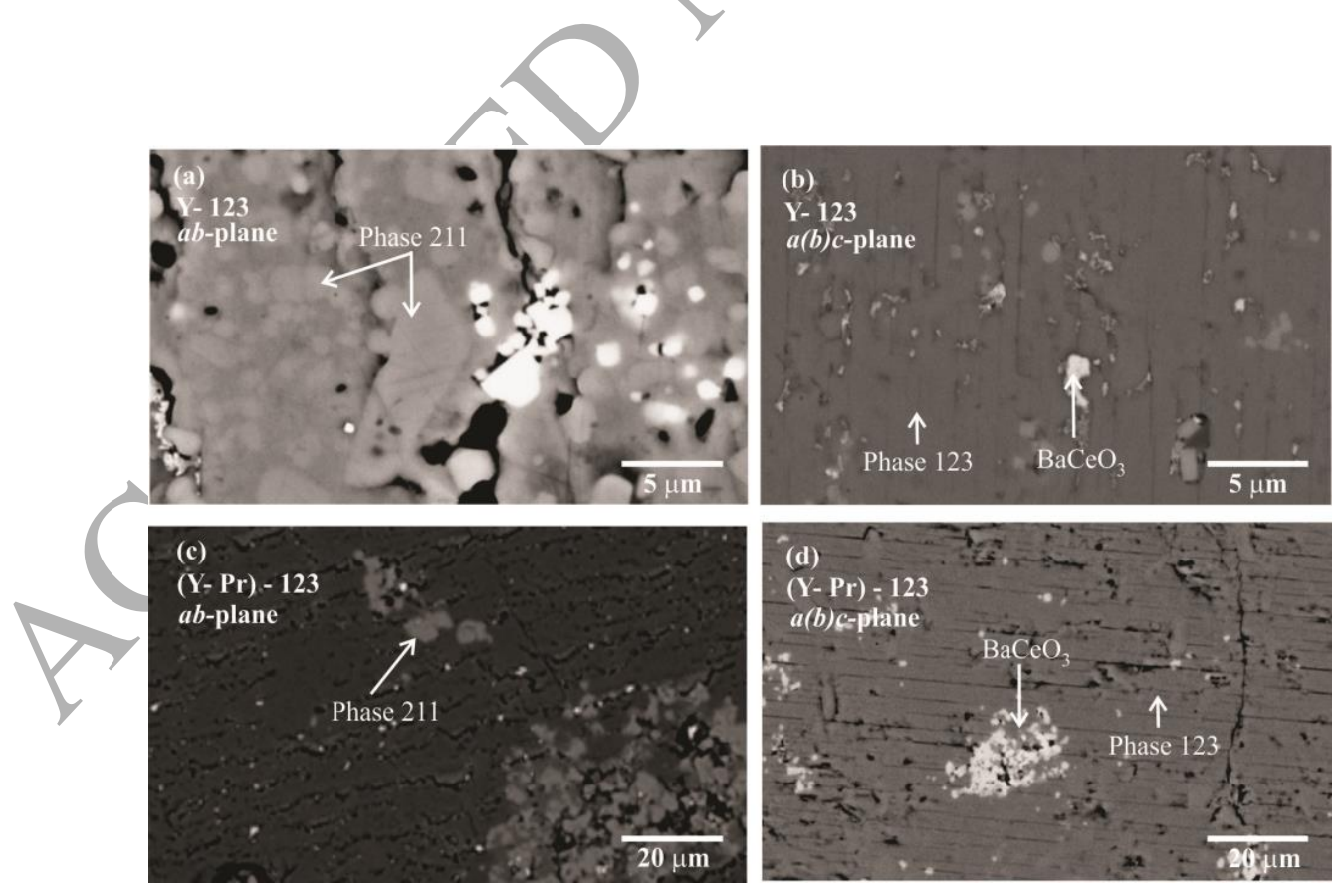


Figure 2: SEM images of $\mathrm{YBa}_{2} \mathrm{Cu}_{3} \mathrm{O}_{7-d}$ (a-b) and $\left(\mathrm{YBa}_{2} \mathrm{Cu}_{3} \mathrm{O}_{7-\delta}\right)_{0.95}$ $\left(\mathrm{PrBa}_{2} \mathrm{Cu}_{3} \mathrm{O}_{7-} \delta\right)_{0.05}$ (c-d) melt textured composite for $a b-$ and $a(b) c$ - plane.

Figure 3(a-b) shows the temperature dependence on the resistivity for $\mathrm{YBa}_{2} \mathrm{Cu}_{3} \mathrm{O}_{7-\delta} \delta$ composite superconductor. The measurements were performed for $I / / a b$ - and $I / / a(b) c$-plane with current $I=10 \mathrm{~mA}$. The results indicate that the sample showed a metallic-like behavior at higher temperatures, and also as expected, the room-temperature resistivity for in-plane measurement was lower than that out-of-plane. For the sake of clarity, the presented curves in Figure (b) were normalized to unity at $100 \mathrm{~K}$. The $T_{c o}$ values are $93.0 \mathrm{~K}$ and $91.0 \mathrm{~K}$ for $1 / / a b$ and $I / / a(b) c$ configurations, respectively. In Figure (c), the corresponding $d \rho / d T$ versus temperature is shown. The plot of $d \rho / d T$ is a simple procedure for magnifying details of the transition. This plot shows clearly that the transitions occurred at different temperatures. The width of transition for this sample, $\Delta T$, defined between $5 \%$ and $95 \%$ of the transition height, were approximately $0.7 \mathrm{~K}$ and $0.9 \mathrm{~K}$ for $1 / / a b$ and $1 / / a(b) c$ configurations, respectively. Figure 3 also shows the maximum $d \rho / d T$, that corresponds approximately to the bulk critical temperature, $T_{c}^{a b}$ and $T_{c}^{a(b) c}$, with the values $93.5 \mathrm{~K}$ and $91.7 \mathrm{~K}$ for both configurations. 

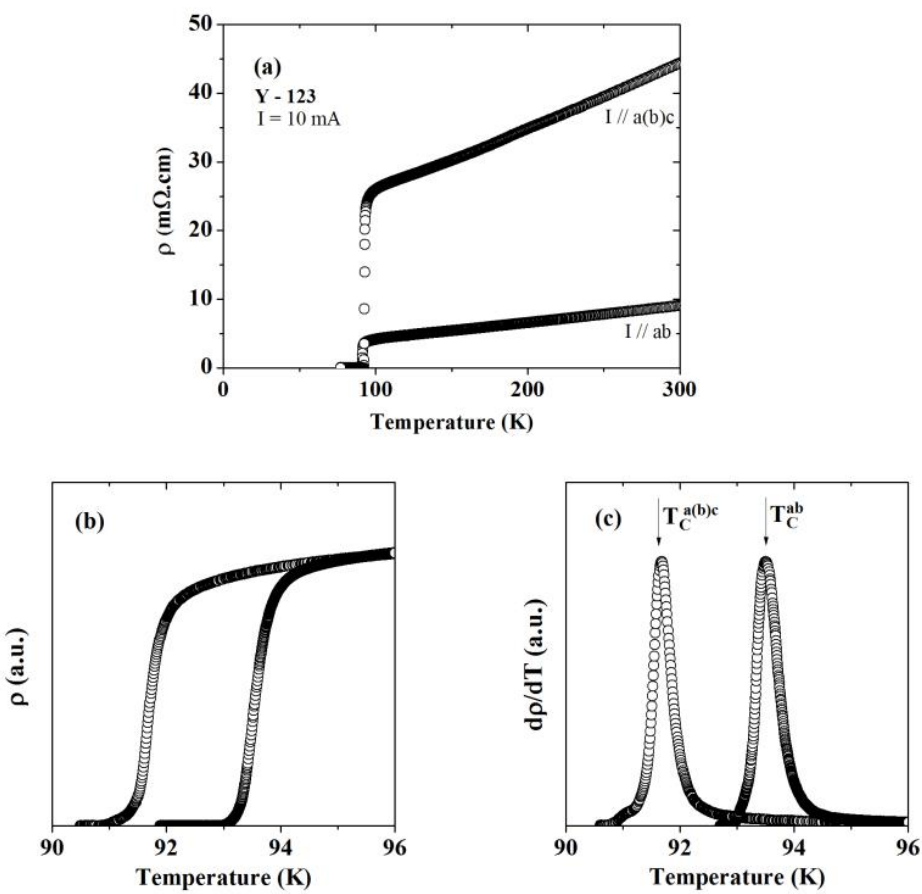

Figure 3: (a) and (b) Temperature dependence on the resistivity for $\mathrm{YBa}_{2} \mathrm{Cu}_{3} \mathrm{O}_{7-} \delta$ melt textured for $I / / a b$ - and I// $a(b) c$-plane; and in (c), $d \rho / d T$ versus temperature for $\mathrm{YBa}_{2} \mathrm{Cu}_{3} \mathrm{O}_{7-\delta}$ melt textured for both planes. The current was $10 \mathrm{~mA}$. In panel (c), the critical temperature $T_{C}$ is shown.

Figure $4(\mathrm{a})$ and (c) presents the temperature dependence on the resistivity for the melt textured $\left(\mathrm{YBa}_{2} \mathrm{Cu}_{3} \mathrm{O}_{7-} \delta\right)_{0.95}-\left(\mathrm{PrBa}_{2} \mathrm{Cu}_{3} \mathrm{O}_{7-} \delta\right)_{0.05}$ composite for $I / / a b$ - and $I / / a(b) c$-plane with current $I=5,10,15$ and $50 \mathrm{~mA}$. The results (not shown) obtained for this sample also revealed a metallic-like behavior at higher temperatures. And also, the room-temperature resistivity for in-plane was lower than that out-of-plane. The $T_{\text {co }}$ values were approximately $89.5 \mathrm{~K}$ and $90.3 \mathrm{~K}$ for configurations $\mathrm{l} / / \mathrm{ab}$ and $\mathrm{l} / / \mathrm{a}(\mathrm{b}) \mathrm{c}$, respectively. Also, as expected, the values were similar regardless of the current. In figures (b) and 
(d) the corresponding $d \rho / d T$ versus temperature are shown. The transitions width were approximately $0.9 \mathrm{~K}$ and $0.7 \mathrm{~K}$ for $1 / / a b$ and $1 / / a(b) c$ configurations, respectively. The bulk critical temperature for this sample was $T_{c}^{a b}=90.5 \mathrm{~K}$ and $T_{c}^{a(b) c}=90.6 \mathrm{~K}$ for $I / / a b$ and $I / / a(b) c$, respectively.
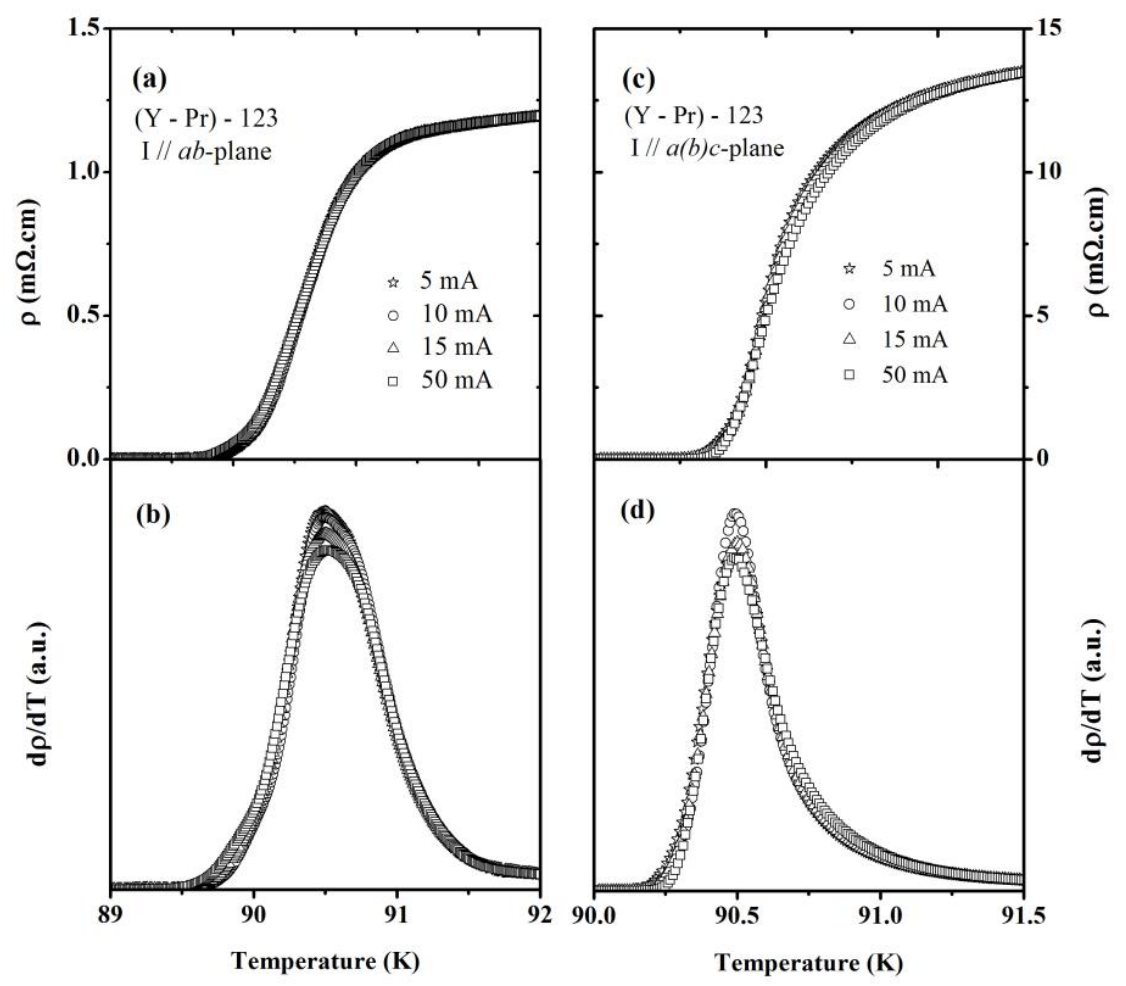

Figure 4: (a) and (c) Temperature dependence on the resistivity for melt textured $\left(\mathrm{YBa}_{2} \mathrm{Cu}_{3} \mathrm{O}_{7-\delta} \delta\right)_{0.95}-\left(\mathrm{PrBa}_{2} \mathrm{Cu}_{3} \mathrm{O}_{7-} \delta\right)_{0.05}$ composite for 1 $/ / a b$ - and $I / / a(b) c$-plane; and in (b) and (d), the corresponding $d \rho / d T$ versus temperature. 
Figure 5 shows DC magnetization measurements performed as a function of temperature in low-field under zero-field-cooling (ZFC) and field-cooling (FC) conditions for $\mathrm{YBa}_{2} \mathrm{Cu}_{3} \mathrm{O}_{7-\delta}$ and $\left(\mathrm{YBa}_{2} \mathrm{Cu}_{3} \mathrm{O}_{7-\delta}\right)_{0.95}-\left(\mathrm{PrBa}_{2} \mathrm{Cu}_{3} \mathrm{O}_{7-\delta}\right)_{0.05}$ melt textured composites. The measurements were carried out in $20 \mathrm{Oe}$ and with the field applied parallel to $a b$-plane. Great difference between the ZFC and FC magnetizations curves could be observed. One characteristic temperature is noteworthy in the curves for both samples. The inflection of the magnetization with lowering temperature denotes $T_{c}$, a temperature below which rapid decrease in magnetization occurs as the result of super-currentinduced diamagnetism. Below $T_{C}$, the ZFC and FC curves strongly split apart with the ZFC magnetization increasing with temperature/reduction. The behavior is stronger for the $Y-123$ sample. Magnetization curves for only ZFC for both samples are shown in detail around the critical temperature in Fig. 5(b). As expected, the curves revealed that the value of the magnetic moment for the $\mathrm{Y}-123$ sample was higher than that for the $(\mathrm{Y}-\mathrm{Pr})-123$ sample. The same curves were seen in temperatures between 90 and $94 \mathrm{~K}$. Superconductivity was observed as a sharp diamagnetic transition at critical temperatures $T_{C}=92.9 \mathrm{~K}$ and $92.4 \mathrm{~K}$ for $\mathrm{Y}-123$ and $(\mathrm{Y}-\mathrm{Pr})-123$ samples, respectively. The curves also showed that the critical temperature was weakly affected by Pr.

Figure 6 shows the magnetization as a function of the applied magnetic field for $\mathrm{YBa}_{2} \mathrm{Cu}_{3} \mathrm{O}_{7-\delta}$ and $\left(\mathrm{YBa}_{2} \mathrm{Cu}_{3} \mathrm{O}_{7-} \delta\right)_{0.95}-\left(\mathrm{PrBa}_{2} \mathrm{Cu}_{3} \mathrm{O}_{7-\delta}\right)_{0.05}$ melt textured composites. The measurements were performed at $15 \mathrm{~K}$, with $\mathrm{H} / / \mathrm{c}$-axis and the magnetization was measured after initially cooling in zero field to $15 \mathrm{~K}$. The sample $\mathrm{Y}-123$ had approximately the same hysteresis compared to that of $(Y-P r)-123$ sample. This will be later correlated with the microstructure of the two samples. And also, it is interesting to note that in both samples the $\mathrm{M}-\mathrm{H}$ curves were asymmetric (for field increasing and decreasing branches) with respect to the magnetic field axis. 
In Fig 6(c), we observed the critical current density measured as a function of the applied magnetic field (up to $\mu_{0} \mathrm{H}=5 \mathrm{~T}$ ) for the $\mathrm{YBa}_{2} \mathrm{Cu}_{3} \mathrm{O}_{7-\delta}$ and $\left(\mathrm{YBa}_{2} \mathrm{Cu}_{3} \mathrm{O}_{7-\delta}\right)_{0.95}-\left(\mathrm{PrBa}_{2} \mathrm{Cu}_{3} \mathrm{O}_{7-\delta}\right)_{0.05}$ melt textured composites. We could also observe that the samples exhibited a similar functional variation of $J_{C}$ with applied field. The values were obtained from magnetization measurements such as Figure $6(a-b)$. These samples presented identical geometry and orientation and were cut from a larger single grain. Also, the critical current density was determined through application of Bean model (as in the usual way) from the width of the positive-field branch of the loop [15-16]. As observed in Figure 6, sample $Y-123$ showed higher critical current densities than that for the $(\mathrm{Y}-\mathrm{Pr})-123$ sample: at $\mu_{0} H(T)=0 \mathrm{~T}$, we obtained $J_{C}=5.85 \times 10^{5} \mathrm{~A} / \mathrm{cm}^{2}$ for $Y-123$ sample, while for $(Y-P r)-123$ sample, $J_{C}=4.72 \times 10^{5} \mathrm{~A} / \mathrm{cm}^{2}$ was observed, a $20 \%$ decrease. 


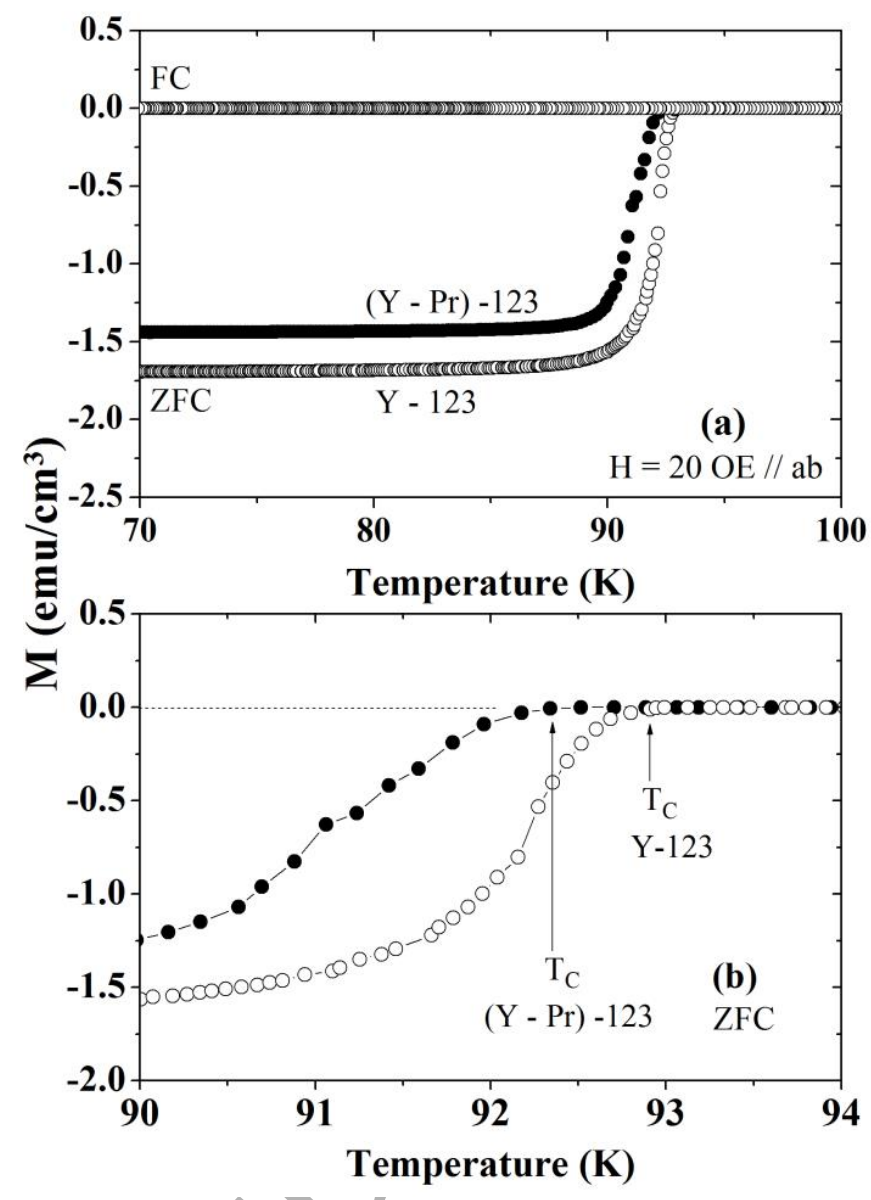

Figure 5: Low-field magnetization ZFC and $\mathrm{FC}$ in $20 \mathrm{Oe} / / a b$-plane versus temperature for $\mathrm{YBa}_{2} \mathrm{Cu}_{3} \mathrm{O}_{7-\delta}$ and $\left(\mathrm{YBa}_{2} \mathrm{Cu}_{3} \mathrm{O}_{7-\delta}\right)_{0.95}$ $\left(\mathrm{PrBa}_{2} \mathrm{Cu}_{3} \mathrm{O}_{7} \delta\right)_{0.05}$ melt textured composites. In Figure (b), magnetization for both samples is shown in more detail around the critical temperature. 
For the sake of comparison, the result of $J_{C}$ for $\mathrm{Y}_{0.95} \mathrm{Pr}_{0.05} \mathrm{Ba}_{2} \mathrm{Cu}_{3} \mathrm{O}_{7-\delta}(\mathrm{YPr}-123)$ melt-textured composite sample prepared using same thermal route [17] is also shown in Figure 6(c). The critical current density for this sample was also determined by applying the Bean model. This curve also exhibited the same functional variation as $J_{C}$ with the applied field observed in other samples. As observed from that figure, sample $\mathrm{YPr}-123$ showed higher critical current densities than that for $\mathrm{Y}-123$ and $(\mathrm{Y}-\mathrm{Pr})-123$ samples. The value observed for $J_{C}$ in $0 \mathrm{~T}$ for $\mathrm{YPr}-123$ sample is $J_{C}=7.48 \times 10^{5} \mathrm{~A} / \mathrm{cm}^{2}$, an increase of $22 \%$ in relation to the $Y-123$ sample.

It is important to point out that the depression of superconductivity by $\operatorname{Pr}$ ion for $(\mathrm{Y}-\mathrm{Pr})-123$ and $\mathrm{YPr}-123$ samples occurred at different scales, with structural resolutions on nano- and micron-metre scales [8-10], when considering the percolation model proposed by Yoshida et al. In this model, the system is regarded as a $2 D$ site-percolation structure built along the $a b$ plane with structural elements of $\mathrm{Y}$-sited and Pr-sited crystal unit cells. Therefore, for the $\mathrm{Y}_{0.95} \mathrm{Pr}_{0.05} \mathrm{Ba}_{2} \mathrm{Cu}_{3} \mathrm{O}_{7-\delta}$ sample, the depression must have occurred at a nano-metre scale while for the $\left(\mathrm{YBa}_{2} \mathrm{Cu}_{3} \mathrm{O}_{7-} \delta\right)_{0.95}-\left(\mathrm{PrBa}_{2} \mathrm{Cu}_{3} \mathrm{O}_{7-}\right.$ $\delta)_{0.05}$ sample, it must have occurred at a micron-metre scale.

Substitutional studies were carried out by Huhtinen et al. on sintered bulk samples of $\mathrm{YBa}_{2} \mathrm{Cu}_{3} \mathrm{O}_{7-\delta}$ to determine the effect of $\mathrm{Pr}$ doping on the formation of effective pinning centers for $J_{C}$ enhancement [18]. The results showed that $\operatorname{Pr}$ substitutions are effective, forming rows of oxygen vacancies with pronounced strain fields in $\mathrm{CuO}_{2}$ planes. These defects are analogous to arrays of normal nanodots in $\mathrm{CuO}_{2}$ planes and, therefore, have strong intragrain pinning interactions with pancake vortices of $\mathrm{CuO}_{2}$ planes forming the mixed state structure. They observed that for $8 \% \mathrm{Pr}$, the increase in $J_{C}$ was almost by a factor of 10, whereas for $10 \%$ doping, the critical current density was seen to get degraded to the level of 2-4\% Pr. 

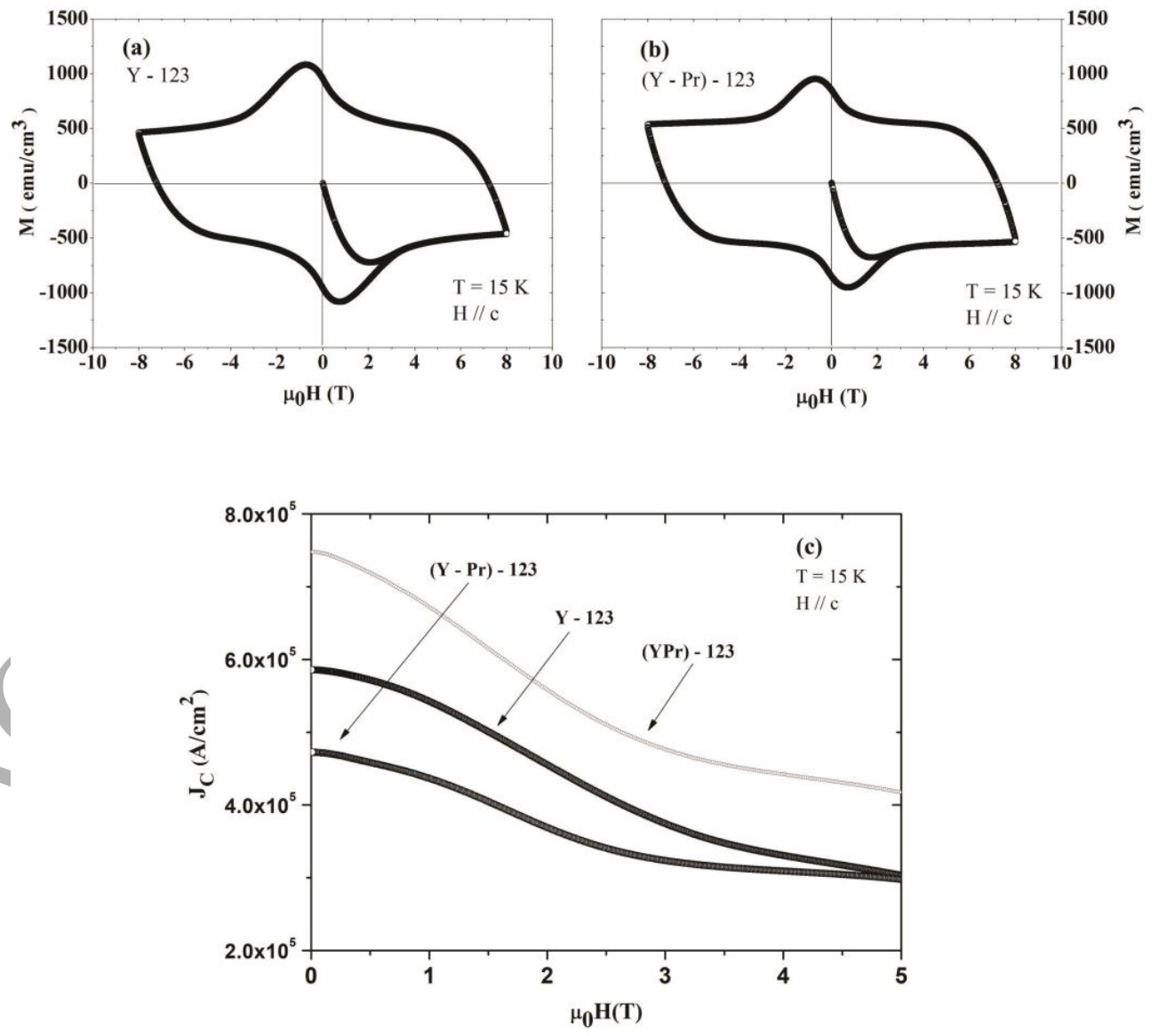
Figure 6: (a-b) Magnetization as a function of the applied magnetic field for $\mathrm{YBa}_{2} \mathrm{Cu}_{3} \mathrm{O}_{7-\delta}$ and $\left(\mathrm{YBa}_{2} \mathrm{Cu}_{3} \mathrm{O}_{7-\delta}\right)_{0.95}-\left(\mathrm{PrBa}_{2} \mathrm{Cu}_{3} \mathrm{O}_{7-\delta}\right)_{0.05}$ melt textured composites. Data was taken after zero field cooling. (c) Critical current density measured as a function of the applied magnetic field for the $\mathrm{YBa}_{2} \mathrm{Cu}_{3} \mathrm{O}_{7-\delta}$ and $\left(\mathrm{YBa}_{2} \mathrm{Cu}_{3} \mathrm{O}_{7-\delta}\right)_{0.95}$ $\left(\mathrm{PrBa}_{2} \mathrm{Cu}_{3} \mathrm{O}_{7-} \delta\right)_{0.05}$ melt textured composites. For the sake of comparison, the result of $J_{C}$ for $\mathrm{Y}_{0.95} \mathrm{Pr}_{0.05} \mathrm{Ba}_{2} \mathrm{Cu}_{3} \mathrm{O}_{7-\delta}((\mathrm{YPr})-123)$ sample is also shown. The measurements were performed at 15 K with $H / /$ c-axis.

\section{Conclusions}

In this study, melt textured $\left(\mathrm{YBa}_{2} \mathrm{Cu}_{3} \mathrm{O}_{7-\delta}\right)_{1-\mathrm{x}}-\left(\mathrm{PrBa}_{2} \mathrm{Cu}_{3} \mathrm{O}_{7-\delta}\right)_{x}(x=0.00$ and $x$ $=0.05$ ) samples were prepared using the top seeding growth technique. The samples were characterized using scanning electron microscopy, X-ray diffraction, magnetization and electrical resistivity. SEM images revealed that the microstructure is consisted of a highly density of grains embedded in a matrix $\mathrm{Y}(\mathrm{Pr})-123$. The $\mathrm{X}$-ray patterns revealed that the samples correspond to the orthorhombic $\mathrm{YBa}_{2} \mathrm{Cu}_{3} \mathrm{O}_{7-\delta}$ phase. From resistivity measurements, the critical temperature was determined to be around $90.5 \mathrm{~K}$ for both samples, however from the magnetic characterization, the superconductivity was observed at critical temperatures $T_{C}=92.9 \mathrm{~K}$ and $92.4 \mathrm{~K}$ for $\mathrm{YBa}_{2} \mathrm{Cu}_{3} \mathrm{O}_{7-\delta}$ and $\left(\mathrm{YBa}_{2} \mathrm{Cu}_{3} \mathrm{O}_{7-} \delta\right)_{0.95}-\left(\mathrm{PrBa}_{2} \mathrm{Cu}_{3} \mathrm{O}_{7-} \delta\right)_{0.05}$ samples, respectively. The critical current densities for the two samples were different, being $20 \%$ lower for the Pr-doped sample. 


\section{Acknowledgements}

This work was partially financed by the CNPq Brazilian Agency under contract $n^{0} 472.746 / 2013-8$.

\section{References}

[1] P. Fox, E. J. Hardman, G. J. Tatlock and D. G. McCartney, Supercond. Sci. Technol.11 (1998) 541.

[2] M. Murakami, M. Morita, K. Doi, M. Miyamoto, Jpn. J. Appl. Phys. 28 (1989) 1189.

[3] M. Q. Tan, X. M. Tao, Q. R. Zhang, Y. B. Xu, Progress in Physics (1995) 15173.

[4] L. Soderholm, K. Zhang, D. G. Hinks, M. A. Beno, J. D. Jorgensen, C. U. Segre, I. K. Schuller, Nature 328 (1987) 604.

[5] J. J. Neumeier, T. Bjornholm, M. B. Maple and I. K. Schuller, Phys. Rev. Lett. 63 (1989) 2516.

[6] G. Y. Guo, W. M. Temmermann, Phys. Rev. B 41 (1990) 6372.

[7] J. Fink, N. Nucker, H. Romberg, M. Alexander, M. B. Maple, J. J. Neumeier, J. W. Allen, Phys. Rev. B 42 (1990) 4823. 
[8] K. Yoshida, Phys. Rev. B 60 (13) (1999) 9325.

[9] K. Yoshida, Phys. Rev. B 76 (2007) 24514.

[10] K. Yoshida, T. Harada and E. Kojima, Supercond. Sci. Technol. 16 (2003) 720.

[11] N. Vilalta, F. Sandimenge, S. Pinol, X. Obradors, J. Mater. Res. 11 (1997) 1238.

[12] A. C. Larson and R.B. Von Dreele, General Structure Analysis System (GSAS), Los Alamos National Laboratory Report LAUR 86 (1994) 748.

[13] B. H. Toby, EXPGUI, a graphical user interface for GSAS, Journal of Applied Crystallographic 34 (2001) 210.

[14] H.B. Radousky, J. Matter. Res. 7 (1992) 1917.

[15] C. P. Bean, Phys. Rev. Lett. 8 (1962) 250.

[16] C. P. Bean, Rev. Mod. Phys. 36 (1964) 31.

[17] Y. A. Opata, J. F. H. L. Monteiro, A. R. Jurelo, P. R. Júnior, E. C. Siqueira, Submitted for publication in Physica C in 2017.

[18] H. Huhtinen, V. P. S. Awana, A. Gupta, H. Kishan, R. Laiho, A. V. Narlikar, Supercond. Sci. Technol. 20 (2007) S159. 